\title{
The evaluation of inflammatory process, endothelial dysfunction and oxidative stress in sleep apnea
}

\author{
Uyku apnesinde inflamatuar süreç, endotelial fonksiyon bozukluğu ve \\ oksidatif stresin incelenmesi \\ Yusuf Dündar', Emel Çadallı Tatar², Güleser Saylam², Hakan Korkmaz³, Ömer Tarık Selçuk4, \\ Ali Özdek ${ }^{5}$, Sadık Ardıç \\ ${ }^{1}$ Department of Otolaryngology, Rize Government Hospital, Rize, Turkey \\ ${ }^{2}$ Department of Otolaryngology, Dıskapn Ylldirm Beyazıt Training and Research Hospital, Ankara, Turkey \\ ${ }^{3}$ Department of Otolaryngology, Ylldrrm Beyazut University Medical Faculty, Ankara, Turkey \\ ${ }^{4}$ Department of Otolaryngology, Antalya Training and Research Hospital, Antalya Turkey \\ 'Department of Otolaryngology, Karabiik University Medical Faculty, Karabiik, Turkey \\ ${ }^{6}$ Sleep Disorders Center, Department of Chest Medicine, Dışkapı Yıldirım Beyazıt Training and Research Hospital, Ankara, Turkey
}

\begin{abstract}
Objective: To investigate the correlation of inflammatory process, endothelial dysfunction and oxidative stress with obstructive sleep apnea (OSA).

Methods: In our prospective cross-sectional clinical study in a tertiary referral hospital, we evaluated 63 patients with newly diagnosed OSA and 9 simple snorers. Each patient was evaluated in terms of additional systemic diseases and laboratory tests. In addition to routine blood analysis; oxidative stress markers (leptine, RBP), vascular endothelial markers (ICAM-I, VCAM-I) and inflammatory markers (Crp, IL-6, TNF-alpha, isoprostane) were analyzed. Polysomnography test was performed and study population was divided into four groups depending on their AHI values. The levels of markers were analyzed and compared between the four groups.

Results: There was a weak correlation between the isoprostane levels and mean apnea duration and also a mild correlation to the maximum apnea duration. A weak correlation was detected between leptine and VCAM levels to age and also a weak negative correlation was detected between CRP levels to age. The leptin levels were found to be mildly correlated to BMI and abdominal circumference. The ICAM levels were found to have a weak correlation to BMI and abdominal circumference.

Conclusion: Our results indicate a correlation between sleep apnea and oxidative stress. These results may help to explain the association of comorbid diseases with OSAS. Further investigators should aim to explain key steps of inflammatory response in sleep apnea.
\end{abstract}

Keywords: Sleep apnea, inflammation, oxidative stress, vascular endothelia.

\begin{abstract}
Özet
Amaç: Uyku apnesinde inflamatuar süreç, endotelial fonksiyon bozukluğu ve oksidatif stresin ilişkisinin incelenmesi.

Yöntem: Üçüncü basamak bir referans hastanesinde planlanan çalışmaya 63 yeni tanı almış uyku apnesi hastası ve 9 basit horlama hastas1 dahil edildi. Hastalar ek sistemik hastalıklar ve laboratuvar testleri açısından değerlendirildi, fizik muayeneleri yapıldı. Rutin laboratuvar testlerine ek olarak oksidatif stres belirteçleri (leptin, RBP), endothelial fonksiyon bozukluğu belirteçleri (ICAM-I, VCAM-I) ve inflamatuar süreç belirteçleri (CRP, IL-6, TNF-alfa, izoprostan) açısından analiz edildi. Hastalar apne hipopne indekslerine göre 4 alt gruba ayrıldı. Gruplar arasında çapraz analizler yapılarak gruplar arasındaki farklılıklar test edildi.

Bulgular: İzoprostan seviyesi ile ortalama apne süresi arasında hafif, maksimum apne süresi arasında orta seviyede korrelasyon gözlendi. Hastaların yaş ortalaması ile leptin ve VCAM-I arasında zayıf pozitif korrelasyon gözlenirken, CRP seviyesi ile ortalama yaş arasında zayıf negatif korelasyon izlendi. Leptin seviyesi ile vücut kitle indeksi ve abdominal çevre arasında orta seviyeli korelasyon izlendi. ICAM-I seviyesi ile vücut kitle endeksi ve karın çevresi arasında zayıf korelasyon mevcuttu.

Sonuç: Çalışmamız sonucunda oksidatif stress ile uyku apnesi arasında ilişki olduğunu tespit ettik. Bu ilişki uyku apnesine eşlik eden komorbid hastalıkların açıklanmasında önemli bir basamak olabilir. Bu konuda yapılacak olan yeni çalışmalarda bu inflamatuar sürecin basamakları ve klinik yansımaları açıklanmaya çalışılmalıdır.
\end{abstract}

Anahtar sözcükler: Uyku apnesi, inflamasyon, oksidatif stress, vasküler endotel.
Correspondence: Yusuf Dündar, MD. Department of Otolaryngology,

Rize Government Hospital, Rize, Turkey.

e-mail: ysfdndr@gmail.com

Received: May 26, 2014; Accepted: June 2, 2014
Online available at:

www.jmedupdates.org doi:10.2399/jmu.2014002007 QR code: 
Obstructive sleep apnea (OSA) is an important health problem with an incidence of $4 \%$ in men and $2 \%$ in women of middle-aged population. ${ }^{[1]}$ OSA is characterized by complete or partial obstruction of breathing due to collapse of upper airway during sleep. It is associated with increased cardiovascular and cerebrovascular morbidity along with increased atherosclerosis and oxidative stress. Inflammatory response may play an important role in the pathogenesis of atherosclerosis. ${ }^{[2]}$

Obstructive sleep apnea associated with chronic inflammatory process of vessels has been described in recent studies. ${ }^{[3]}$ Chronic inflammation has a potential risk of permanent vascular damage which may lead to stroke or myocardial infarction. The inflammatory process in this disease is most probably induced by chronic intermittent hypoxemia. An inflammatory response starts with TNF and continues with induction of other acute-phase proteins such as CRP, IL-6, retinol-binding protein (RBP), isoprostane. It was proposed that endothelial dysfunction and resulting vascular damage in OSA may lead to vasoconstriction, hypercoagulability-thrombosis and eventually cardiovascular/cerebrovascular complications. ${ }^{[4]}$ Circulating levels of soluble adhesion molecules such as intercellular adhesion molecule1 (ICAM-1) and vascular cellular adhesion molecule-1 (VCAM-1) were detected to be elevated in OSA patients. ${ }^{[5]}$

Circulating adipokine levels were found to be related with insulin resistance and reduced sleep time. ${ }^{[6]}$ Retinolbinding protein is one of the adipokines and found to be in elevated levels in OSA. The RBP level reduces with CPAP therapy. Leptin is a protein, derived from adiposite tissue. Leptin is found to be in elevated levels in OSA. Endothelial tissue has the leptine receptors. Elevated leptin levels may play a role in atherosclerotic process and comorbid diseases in OSA.

In the present study, our aim was to investigate the correlation of inflammatory process, endothelial dysfunction and oxidative stress with OSA.

\section{Materials and Methods}

\section{Study Design}

The study was approved by the ethical committee of Dışkapı Yıldırım Beyazıt Training and Research Hospital. In this cohort study 63 patients with newly diagnosed OSA and 9 simple snorers were evaluated. The subjects were examined by polysomnography (PSG) and blood tests, and they were stratified to 4 groups depending on their AHI values. The first group had 9 simple snorers with $\mathrm{AHI}<5$. The second group had 28 subjects with mild OSA
$(5<\mathrm{AHI}<15)$; the third group had 18 subjects with moderate OSA $(15<\mathrm{AHI}<30)$; the fourth group had 17 subjects with severe OSA (AHI>30).

After obtaining detailed medical history and performing physical examination blood tests were done. For each subject body mass index (BMI), neck circumference (NC), abdominal circumference (AC), Epworth sleepiness scale (ESS) were determined. Then all subjects underwent PSG (Compumedics, E serial, PSG 3, Victoria, Australia) with 16 channel sleep test at the sleep laboratory of our hospital. The sleep data obtained from each patient was assessed by the same clinician. Apnea-hypopnea index (AHI), maximum apnea and hypopnea durations, mean apnea and hypopnea durations, lowest $\mathrm{O}_{2}$ level, oxygen desaturation index were determined.

\section{Blood Collection and Biochemical Analysis}

Blood samples were taken from anterior cubital vein after minimum 8 hours of fasting between 09:00 and 10:00 a.m. Blood samples were kept at $-4{ }^{\circ} \mathrm{C}$ until centrifugation, and after centrifugation plasma was stored at $-70^{\circ} \mathrm{C}$ until assaying. Ultrasensitive CRP concentration analysis was carried out by using ultrasensitive latex-enhanced immunoassay. Assay of TNF- $\alpha$, IL-6, isoprostane and RBP parameters were done by quantitative sandwich enzyme immunoassay technique. Leptine levels were analyzed by radioimmunoassay technique and circulating levels of ICAM and VCAM were investigated by enzyme immunoassay technique.

\section{Statistical Analysis}

The clinical and PSG parameters, and levels of inflammatory markers were analysed with respect to the severity of OSA. The comparison of four groups was performed by SPSS v.11.5 (SPSS Inc., Chicago, IL, USA). Parametric test assumptions were controlled for choosing the appropriate statistical analysis. Multivariate analysis of variance (MANOVA) test was used for comparing BMI, neck circumference and abdominal circumference variables. One way ANOVA test was used for comparing Epworth Sleepness Scale. Kruskal-Wallis test was used for comparing inflammatory markers and oxidative stress markers. Vascular endothelial markers were analyzed with MANOVA test. Association between the continuous variables was determined by Pearson correlation coefficient. Significance value was considered as $\mathrm{p}<0.05$.

\section{Results}

There were 48 male and 24 female patients, and mean age was 47.873 (range: $24-75$ ) years. The clinical findings of 
Table 1. Characteristics of study population.

\begin{tabular}{|c|c|c|c|c|c|}
\hline & Group I $(n=9)$ & Group II $(n=28)$ & Group III $(n=18)$ & Group IV $(n=17)$ & $p$ value \\
\hline BMl & $27.82 \pm 4.46$ & $31.82 \pm 4.72$ & $31.00 \pm 5.56$ & $30.00 \pm 7.01$ & 0.276 \\
\hline Neck circumference & $38.11 \pm 4.45$ & $40.96 \pm 3.69$ & $40.88 \pm 3.15$ & $43.75 \pm 3.19$ & $0.003^{*}$ \\
\hline Abdominal circumference & $102.33 \pm 19.08$ & $109.53 \pm 11.37$ & $107.41 \pm 12.10$ & $101.50 \pm 27.50$ & 0.445 \\
\hline Epworth & $13.55 \pm 12.36$ & $8.85 \pm 5.67$ & $8.50 \pm 4.25$ & $12.52 \pm 5.03$ & 0.076 \\
\hline
\end{tabular}

*p $<0.05$ for Group I - Group IV.

the study population are given in Table 1 . There was no statistically significant difference between the groups with respect to age, BMI, abdominal circumference and ESS. Neck circumference was significantly different between Group I to Group IV.

Median areas of neochondrogenesis in the control and the mean levels of inflammatory parameters and their correlation to OSA severity are given in Table 2. The mean leptine level seems to be elevated in the second group, the mean isoprostane, mean RBP and mean VCAM levels seem to be elevated in the third group and the mean IL-6 level seems to be elevated in fourth group; but we could not find any statistically significant difference between the groups.

There was a weak correlation between the isoprostane levels and mean apnea duration and also a mild correlation to the maximum apnea duration. A weak correlation was detected between leptine and VCAM levels to age. A weak negative correlation was detected between CRP levels and age. The leptin levels were found to be mildly correlated to $\mathrm{BMI}$ and abdominal circumference. The ICAM levels were found to have a weak correlation to BMI and abdominal circumference. We could not find any statistically significant correlation between IL-6 and RBP levels, TNF levels and other OSA related parameters. There was no association between AHI severity and the analyzed parameters.

All data were analyzed and compared simple snoring group (Group 1) and newly diagnosed sleep apnea groups
(Group $2+$ Group 3 + Group 4). We could not find any statistical significant correlation between the first group and the other newly diagnosed sleep apnea groups.

\section{Discussion}

Obstructive sleep apnea is a common and important sleep disorder. However, its ethiopathologic process is not clear yet. OSA has a potential risk of cardiovascular and cerebrovascular morbidity. Many investigators reported that the association between OSA and cardiovascular/cerebrovascular morbidity is independent of obesity. The cessation of airflow during sleep leads to intermittent hypoxia and re-oxygenation. Intermittent hypoxia may lead to oxidative stress and increased reactive oxygen species (ROS). ${ }^{[7]}$ ROS may damage endothelial tissue that is related to atherosclerosis. Atherosclerotic process may play a serious role in acute myocardial infarction and stroke. Long term intermittent hypoxia may be responsible for neuronal changes via proinflammatory activation, increased oxidative stress eventually apoptosis and gliosis. ${ }^{[8]}$

Intermittent hypoxia in OSA resembles ischemia-reperfusion cycles due to decreasing blood oxygen content during apnea/hypopnea. An increase in the production of ROS was reported with ischemia-reperfusion. Depending on these findings, OSA may cause an increase in the ROS levels. ${ }^{[7]}$ An increased production of superoxide from neutrophils and monocytes in OSA patients was also reported. ${ }^{[9]}$ TNF- $\alpha$ has a critical role in inflammatory process, ${ }^{[10]}$ which

Table 2. Mean values of parameters for each study group.

\begin{tabular}{lcccc} 
& Group I $(\mathbf{n}=\mathbf{9})$ & Group II $(\mathbf{n}=\mathbf{2 8})$ & Group III $(\mathbf{n = 1 8 )}$ & Group IV (n=17) \\
\hline Isoprostane & $8.82 \pm 1.32$ & $9.30 \pm 3.84$ & $14.26+/ 16.32$ & $9.08 \pm 3.78$ \\
CRP & $4.55 \pm 3.08$ & $7.56 \pm 7.76$ & $7.40 \pm 7.75$ & $6.00 \pm 3.61$ \\
IL-6 & $1.41 \pm 0.79$ & $3.07 \pm 3.12$ & $3.34 \pm 4.47$ & $8.29 \pm 24.96$ \\
Leptine & $45.62 \pm 37.01$ & $61.87 \pm 38.80$ & $38.45 \pm 35.53$ & $43.48 \pm 33.59$ \\
RBP & $39.65 \pm 12.88$ & $36.19 \pm 14.59$ & $44.15 \pm 11.85$ & $37.69 \pm 12.46$ \\
I-CAM & $29.57 \pm 6.66$ & $30.19 \pm 8.31$ & $29.87 \pm 7.05$ & $31.74 \pm 5.95$ \\
V-CAM & $18.92 \pm 6.28$ & $20.02 \pm 5.24$ & $24.54 \pm 8.07$ & $21.71 \pm 6.40$ \\
TNF & $2.61 \pm 1.99$ & $2.15 \pm 1.96$ & $2.05 \pm 1.17$ & $3.04 \pm 3.54$ \\
\hline
\end{tabular}


Table 3. Correlations of parameters.

\begin{tabular}{lcccccccc}
\hline & Isoprostane & CRP & IL-6 & Leptine & RBP & I-CAM & V-CAM & TNF \\
\hline BMI & -0.012 & 0.034 & 0.058 & $0.614^{+}$ & -0.075 & 0.232 & -0.020 & -0.121 \\
AHI & -0.006 & 0.102 & 0.023 & -0.112 & 0.010 & 0.105 & 0.032 & -0.012 \\
Epworth & -0.055 & -0.111 & -0.195 & -0.213 & -0.058 & 0.026 & -0.102 & -0.064 \\
Neck circumference & 0.120 & 0.128 & 0.205 & -0.019 & 0.113 & 0.199 & 0.048 & 0.093 \\
Abdominal circumference & 0.107 & 0.090 & 0.101 & $0.443^{+}$ & 0.006 & $0.263^{*}$ & 0.127 & -0.056 \\
Apnea-hypopnea index & 0.030 & -0.001 & 0.028 & -0.077 & -0.036 & 0.170 & 0.092 & -0.005 \\
Mean apnea duration & $0.276^{*}$ & -0.039 & 0.042 & -0.085 & 0.018 & 0.063 & -0.036 & 0.060 \\
Maximum apnea duration & $0.392^{+}$ & -0.002 & 0.026 & -0.012 & 0.056 & 0.105 & -0.068 & -0.031 \\
Mean hypopnea duration & 0.024 & -0.032 & 0.068 & -0.231 & -0.016 & 0.002 & 0.114 & 0.178 \\
Maximum hypopnea duration & 0.223 & 0.068 & 0.079 & -0.143 & 0.143 & 0.153 & 0.125 & -0.010 \\
Lowest SOz & 0.076 & 0.039 & 0.003 & 0.071 & -0.034 & -0005 & -0.006 & 0.084 \\
Mean desaturation & -0.082 & 0.048 & -0.012 & 0.156 & -0.069 & -0.012 & -0.071 & -0.058 \\
Age & -0.023 & $-0.249^{*}$ & -0.017 & $0.245^{*}$ & -0.141 & 0.092 & $0.273^{*}$ & -0.044 \\
\hline
\end{tabular}

${ }^{*}$ Correlation is significant at the 0.05 level, ${ }^{+}$Correlation is significant at the 0.01 level.

regulates the inflammatory gene expression. ${ }^{[11]}$ Eventually TNF- $\alpha$ induces the other inflammatory mediators such as IL-6, CRP. Many clinical studies support the correlation of CRP levels with atherosclerosis and stroke. ${ }^{[12,13]}$ Furthermore, reduction of CRP levels after an adequate continuous positive airway pressure (CPAP) therapy has been reported by Steiropoulos et al. ${ }^{[14]}$ This result also supports the association between OSA and inflammation.

Oxidative stress in OSA may help to explain cardiovascular/neurovascular complications. A hypoxia and re-oxygenation cycle can induce the oxidative stress which leads to increased generation of ROS followed by damage to the endothelial tissues. Isoprostanes are produced by ROS induced peroxidation from arachidonic acid, and 8-isoprostane is one of the earliest oxidative stress markers. ${ }^{[15]}$ Its blood levels are found to be elevated with OSA and decreased after the CPAP treatment. ${ }^{[16]}$

Current data demonstrates that adipose tissue acts as an active endocrine organ and releases many bioactive mediators which modulate blood pressure, lipid metabolism, atherosclerosis and inflammation. ${ }^{[17]}$ Leptin is the one of adipocyte derived proteins which is induced by ob gene. Leptin level is related with body fat content. Recent data has shown that, leptin is an independent risk factor for cardiovascular diseases. ${ }^{[18]}$ Leptin levels were found to be elevated in $\mathrm{OSA}^{[19]}$ and decreased with CPAP therapy. ${ }^{[20]}$ Endothelial tissue has the leptin receptors; it may play a role in atherosclerosis pathogenesis.

Retinol-binding protein is an adipokine, which is related to insulin resistance. ${ }^{[2]} \mathrm{RBP}$ modulates the insulin sensitivity in peripheral tissue. Harsch et al. reported the association of OSA and RBP. ${ }^{[2]}$ They found increased RBP levels in moderate/severe OSA patients than those of the control groups; but no correlation between RBP and apnea related parameters. Interestingly, reduction of serum RBP levels with CPAP therapy was reported by Evagelia et al. ${ }^{[23]}$ Diabetes mellitus (DM) and related complications in OSA may explain this correlation.

Cardiovascular complications may be related with endothelial dysfunctions. Endothelial dysfunction is described with imbalance of inflammatory mediators, vascular smooth muscle proliferation, hypercoagulobility, thrombosis and eventually adverse cardiovascular events. ${ }^{[4]}$ Impaired endothelial functions were reported. ${ }^{[4]}$ The potential mechanism depends on hypoxemia due to ROS generation and systemic inflammation. The association of obesity, hypertension, and hyperlipidemia with OSA was reported. These co-morbid diseases may contribute to adverse effects on endothelium. The circulating levels of ICAM and VCAM were reported as higher in OSA patients than those of the control groups. ${ }^{[24]}$ Adhesion molecules have an important role in atherosclerosis. ${ }^{[25]}$

The limitations of our study include the small number of subjects and non-homogen patient groups. Further investigation should include larger subject groups so that association of co-morbid diseases and apnea related parameters may be deeply analyzed. The increased risk of co-morbid diseases can be predicted depending on such findings.

\section{Conclusion}

We have evaluated the inflammatory markers, endothelial dysfunction markers and oxidative stress markers in OSA. Current data support the association of cardiovascular/cerebrovascular complications and OSA. The strongest patho- 
physiologic process depends on oxidative stress and chronic inflammatory response. Determining all the key steps of inflammatory response and endothelial dysfunction may be helpful in sleep apnea treatment. Our results indicate an association between oxidative stress and apnea duration during sleep. Further studies in larger series may explain all the pathophysiologic processes of co-morbid diseases in OSA.

Conflict of Interest: No conflicts declared.

\section{References}

1. Young T, Palta M, Dempsey J, Skatrud J, Weber S, Badr S. The occurrence of sleep-disordered breathing among middle-aged adults. N Engl J Med 1993;328:1230-5.

2. Libby P, Ridker PM, Maseri A. Inflammation and atherosclerosis. Circulation 2002;105:1135-43.

3. Yokoe T, Minoguchi K, Matsuo H, et al. Elevated levels of Creactive protein and interleukin-6 in patients with obstructive sleep apnea syndrome are decreased by nasal continuous positive airway pressure. Circulation 2003;107:1129-34.

4. Ip MS, Tse HF, Lam B, Tsang KW, Lam WK. Endothelial function in obstructive sleep apnea and response to treatment. Am J Respir Crit Care Med 2004;169:348-53.

5. Chin K, Nakamura T, Shimizu K, et al. Effects of nasal continuous positive airway pressure on soluble cell adhesion molecules in patients with obstructive sleep apnea syndrome. Am J Med 2000;109:562-7.

6. Hayes AL, Xu F, Babineau D, Patel SR. Sleep duration and circulating adipokine levels. Sleep 2011;34:147-52.

7. Kang IG, Jung JH, Kim ST. The effect of obstructive sleep apnea on DNA damage and oxidative stress. Clin Exp Otorhinolaryngol 2013;6:68-72.

8. Decker MJ, Jones KA, Solomon IG, Keating GL, Rye DB. Reduced extracellular dopamine and increased responsiveness to novelty: neurochemical and behavioral sequelae of intermittent hypoxia. Sleep 2005;28(2):169-76.

9. Schulz R, Mahmoudi S, Hattar K, et al. Enhanced release of superoxide from polymorphonuclear neutrophils in obstructive sleep apnea. Impact of continuous positive airway pressure therapy. Am J Respir Crit Care Med 2000;162(2 Pt 1):566-70.

10. Li Q, Verma IM. NF-kappaB regulation in the immune system. Nat Rev Immunol 2002;2:725-34.

11. Ryan S, Taylor CT, McNicholas WT. Systemic inflammation: a key factor in the pathogenesis of cardiovascular complications in obstructive sleep apnoea syndrome? Postgrad Med J 2009;85(1010): 693-8.
12. Burke AP, Tracy RP, Kolodgie F, et al. Elevated C-reactive protein values and atherosclerosis in sudden coronary death: association with different pathologies. Circulation 2002;105:2019-23.

13. Haverkate F, Thompson SG, Pyke SD, Gallimore JR, Pepys $\mathrm{MB}$. Production of $\mathrm{C}$-reactive protein and risk of coronary events in stable and unstable angina. European Concerted Action on Thrombosis and Disabilities Angina Pectoris Study Group. Lancet 1997;349(9050):462-6.

14. Celec P, Hodosy J, Behuliak M, et al. Oxidative and carbonyl stress in patients with obstructive sleep apnea treated with continuous positive airway pressure. Sleep Breath 2012;16:393-8.

15. Lawson JA, Rokach J, FitzGerald GA. Isoprostanes: formation, analysis and use as indices of lipid peroxidation in vivo. J Biol Chem 1999;274:24441-4.

16. Ntalapascha M, Makris D, Kyparos A, et al. Oxidative stress in patients with obstructive sleep apnea syndrome. Sleep Breath 2013;17:549-55.

17. Alam I, Lewis K, Stephens JW, Baxter JN. Obesity, metabolic syndrome and sleep apnoea: all pro-inflammatory states. Obes Rev 2007;8:119-27.

18. Mancuso M, Bonanni E, LoGerfo A, et al. Oxidative stress biomarkers in patients with untreated obstructive sleep apnea syndrome. Sleep Med 2012;13:632-6.

19. Christou K, Kostikas K, Pastaka C, Tanou K, Antoniadou I, Gourgoulianis KI. Nasal continuous positive airway pressure treatment reduces systemic oxidative stress in patients with severe obstructive sleep apnea syndrome. Sleep Med 2009;10:8794.

20. Harsch IA, Konturek PC, Koebnick C, et al. Leptin and ghrelin levels in patients with obstructive sleep apnoea: effect of CPAP treatment. Eur Respir J 2003;22:251-7.

21. Graham TE, Yang Q, Blüher M, et al. Retinol-binding protein 4 and insulin resistance in lean, obese, and diabetic subjects. N Engl J Med 2006;354:2552-63.

22. Harsch IA, Schahin SP, Radespiel-Tröger M, et al. Continuous positive airway pressure treatment rapidly improves insulin sensitivity in patients with obstructive sleep apnea syndrome. Am J Respir Crit Care Med 2004;169:156-62.

23. Nena E, Steiropoulos P, Tzouvelekis A, et al. Reduction of serum retinol-binding protein-4 levels in nondiabetic obstructive sleep apnea patients under continuous positive airway pressure treatment. Respiration 2010;80:517-23.

24. Ohga E, Nagase T, Tomita T, et al. Increased levels of circulating ICAM-1, VCAM-1, and L-selectin in obstructive sleep apnea syndrome. J Appl Physiol 1999;87:10-4.

25. Jang Y, Lincoff AM, Plow EF, Topol EJ. Cell adhesion molecules in coronary artery disease. J Am Coll Cardiol 1994;24:1591-601.

This is an open access article distributed under the terms of the Creative Commons Attribution-NonCommercial-NoDerivs 3.0 Unported (CC BYNC-ND3.0) Licence (http://creativecommons.org/licenses/by-nc-nd/3.0/) which permits unrestricted noncommercial use, distribution, and reproduction in any medium, provided the original work is properly cited.

Please cite this article as: Dündar Y, Çadallı Tatar E, Saylam G, Korkmaz H, Selçuk ÖT, Özdek A, Ardıç S. The evaluation of inflammatory process, endothelial dysfunction and oxidative stress in sleep apnea. J Med Updates 2014;4(2):61-65. 